\title{
Does Corporate Tax Avoidance Influence Firm Leverage of Vietnamese Listed Companies?
}

\author{
Hoang Thi Mai Khanh, Nguyen Vinh Khuong \\ Faculty of Accounting and Auditing, University of Economics and Law, VNU-HCM, Ho Chi Minh City, Vietnam \\ Email: khanhhtm@uel.edu.vn
}

How to cite this paper: Khanh, H.T.M. and Khuong, N.V. (2019) Does Corporate Tax Avoidance Influence Firm Leverage of Vietnamese Listed Companies? Theoretical Economics Letters, 9, 1070-1078. https://doi.org/10.4236/tel.2019.94069

Received: February 15, 2019

Accepted: April 23, 2019

Published: April 26, 2019

Copyright $\odot 2019$ by author(s) and Scientific Research Publishing Inc. This work is licensed under the Creative Commons Attribution International License (CC BY 4.0).

http://creativecommons.org/licenses/by/4.0/

(c) (i) Open Access

\begin{abstract}
Corporate tax avoidance is defined by reducing taxes for any particular purpose, extending from the gracious remission of taxes expense arising from inconsistent customs for financial statements. In this paper, we examine the association between corporate tax avoidance and firm leverage. The trade-off theory is significant for explaining the relationship between tax avoidance behaviour and firm leverage. Consequently, the company directs to allow tax avoidance behaviour and accept the company's leverage at a higher level than usual. The consequences commence to transaction costs, financial risks when viewing at company health from financial statements, but will maintain the company achieves the expected tax rates. We utilize STATA to test GMM on a sample of Vietnam listed firms data over the period 2010-2016. The sample data of 125 companies in the period from 2010 to 2016, all 875 observations were used for the analysis. The results show that there is a significant positive relationship between corporate tax avoidance on firm leverage in Vietnam. The research is essential to the regulator in controlling tax costs for companies, for investors in analyzing a corporate financial situation.
\end{abstract}

\section{Keywords}

Corporate Tax Avoidance, Firm Leverage, Trade-Off Theory, Emerging Market

\section{Introduction}

Tax shields possibly influence more than just firm leverage ratio, and stock returns can be changed. Moreover, if tax shields interchange for debt-induced tax reductions, sheltering could grow financial slack, decrease anticipated bankruptcy rates, improve credit quality, and diminish the cost of debt.

The previous study has recommended that tax avoidance may be detected, practicing, continuing, and correlated with different exchange results. Following 
Dyreng, Hanlon, and Maydew [1], top managers significantly impact their corporate tax avoidance. Some firms are adequate to skirt or defer tax payments during the long periods [3]. Graham and Tucker [3] show that the association between debt and tax avoidance in the context of corrupt tax avoidance. Nevertheless, the impact of tax avoidance on the firm's leverage is moderately unexplored.

Our study investigates the influence of tax avoidance on firm leverage in a developing market. We use sample data from listed firms on the Ha Noi Stock exchange and Ho Chi Minh City Stock exchange from 2010 to 2016. We utilize GMM to solve the potential endogeneity problem. In developing market context, there are some control variables represent this market such as firm growth rates, firm size, profit, audit quality, and tangible assets.

According to Dyreng et al. [2], most of the listed company practicing tax avoiders by the long-run cash effective tax rate (ETR). Following Dyreng et al. [1] [2], ETR can reveal capturing tax avoidance behavior. The results of this study showed that there is a positive relationship between tax avoidance and firm leverage. According to trade-off theory, after a refinancing event tax, avoiders control approximately higher leverage. Previous research results show that through general tax avoidance strategy, tax avoiders consider leverage is the most important impact. At a refinancing point, there is a positive relationship between tax avoidance and issuing debt. But, the results are weak and sensitive to alternative definitions.

According to trade-off theory, previous research show that most of the firm using tax avoidance tend to adopt more liabilities in their capital structures [3]-[8]. The results show the impact of tax avoidance on leverage is small but it's not significant in their structure. However, at refinancing point, this impact is higher, so tax avoiders combined with debt to effect on general tax avoidance strategy.

In the emerging market, this article supports the current discussion by considering the association between tax avoidance behavior and firm leverage. Following Dyreng et al. [2], firms maintain low cash ETRs in long-terms have higher firm leverage on medium. This study contributes to subsisting literature by investigating the relationship between corporate tax avoidance and firm leverage in the circumstances of trade-off theory in emerging markets similar to Vietnam. This is significant in examining the existence of trade-off theory in the context of Vietnam when the level of financial leverage is quite high. Furthermore, there is non-research on corporate tax avoidance and firm leverage in Vietnam that the reason why this is empirical is vital. This makes sense for researchers to compare the relationship between avoiding corporate taxes and leveraging companies in different contexts of legal and political systems. Our sample is 125 listed firms which disclose financial reporting and audit report covering the period from 2010 through 2016. That represents population nearly 300 listed firms (the non-financial companies were listed before 2009). Moreover, previous studies used only two measures of tax avoidance (the annual cash effective tax rate, the 
long-run cash effective tax rate) to influence leverage [4] [5] [7]. We utilize three ways (cash effective tax rate, the long-run cash effective tax rate, and the book-tax difference) to measures corporate tax avoidance. We employ all three ways to measure the prevalence and generalize the concept of corporate tax avoidance. This will support the research to understand the aspects of corporate tax avoidance and validate the robustness of research. Whereby, increasing the persuasion for the stock market with a small market capitalization alike Vietnam. Finally, the study comparison conflicting results when using different measures for corporate tax avoidance but this is explained through trade-off theory and agent theory. This considerably expands the explanation by the theory of the relationship between corporate tax avoidance and firm leverage.

The rest of the paper proceeds as follows. The next section of the paper shows the data and methodology, Section 3 is the findings and disscussion, finally Section 4 presents the conclusion.

\section{Data and Methodology}

\subsection{Data}

Research methods are applied in accordance with secondary data to investigate the relationship between variables in the research model. Research data is collected from the consolidated financial statements of companies listed on the Vietnamese stock market through Thomson Reuters EIKON at the University of Economics and Law. After collecting, we conveyed incomplete data filtering and calculation of research variables. A total of 125 companies listed on the Ho Chi Minh City Stock Exchange and Hanoi Stock Exchange were collected during the period 2010-2016, corresponding to 875 observations. Our sample does not comprise banking, insurance and finance companies. Therefore, the research sample includes non-financial companies to increase the comparability of research results to previous investigations in different economies [9] [10].

\subsection{Model}

We are using Arellano and Bond [11] linear dynamic GMM to account for the omitted variable problem, country-specific heterogeneity, endogeneity issue, and the panel data is unique included lagged values. If the regression results in heteroskedasticity, autocorrelation or both phenoms, then the research will apply the general least squares method (GLS) to regress research model to succeed the above deficiencies. To solve the endogenous problem due to the simultaneous relationship between the dependent variable and the independent variable in the research model [12]. The dynamic GMM approach was implemented to the results of the estimation are the most reliable when compared to FEM and REM. Therefore, assume that firms can immediately substitute the value of a company subsequent a variation in firm characteristics, tax avoidance, or additional random cause.

The regression model can be specified as follows: 


$$
\begin{aligned}
L E V_{i, t}= & \mu L E V(-1)_{i, t}+\delta_{1} C T A_{i, t}+\delta_{2} \operatorname{SIZE}_{i, t}+\delta_{3} R O A_{i, t} \\
& +\delta_{4} \operatorname{GROWTH}_{i, t}+\delta_{5} P P E_{i, t}+\delta_{5} B I G 4_{i, t}+\varepsilon_{i, t}
\end{aligned}
$$

where $i$ and $t$ are firm and time subscripts, respectively, and $\varepsilon_{i t}$ is the error term.

\section{Dependent variable}

$L E V$ is measure of the firm leverage, which is calculated as short-term and long-term debt for the year divided by total asset at year-end [4] [5] [7].

\section{Independent variable}

There are three measures of corporate tax avoidance. Both the first and second measures begin at the view corporate tax avoidance consider as firm's tax burden [2].

The first measure: According to Cheng et al. [13], CURRENTETR is account as:

$$
\text { CURRENTETR }_{i, t}=\frac{\left(\text { Total Tax Expense }_{i, t}-\text { Deferred Tax Expense }_{i, t}\right)}{\text { Pretax Income }_{i, t}}
$$

Consistent with prior literature, we restrict CURRENTETR to fall in the interval $[0,1][14]$.

The second measure: According to prior literature [1] [2] [13] [15], CASHETR is is account as:

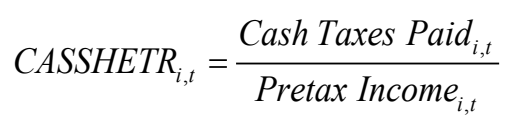

The third measure: Book-Tax Difference $(B T D)$ generally utilized in tax literature. The process is calculated through two stages. The first step, the measure of accrual-based earnings management through discretionary accruals [16]. The second step, tax avoidance will be the residual of Equation (3), which is not explained by accrual-based earnings management.

The discretionary accruals $(D A)$ are calculated as the residuals from:

$$
\begin{gathered}
\frac{T A C_{i, t}}{A_{i, t-1}}=\beta_{1} \frac{1}{A_{i, t-1}}+\beta_{2} \frac{\Delta\left(R E V_{i, t}-A R_{i, t}\right)}{A_{i, t-1}}+\beta_{3} \frac{P P E_{i, t}}{A_{i, t-1}}+\beta_{4} \frac{R O A_{i, t}}{A_{i, t-1}}+\varepsilon_{i, t} \\
D A_{i, t}=T A C_{i, t}-N D A_{i, t} \\
B T D_{i, t}=\beta_{1} D A_{i, t}+u_{j}+e_{i, t} \\
C T A_{i, t}=u_{j}+e_{i, t}
\end{gathered}
$$

where: $B T D_{i, t}$ is the book-tax difference divided by total assets for firm $i$ in year $t$, $T A C$ : total accruals, $D A$ : discretionary accruals, $N D A_{i, t}$ Non discretionary accruals for firm $i$ in year $t, A_{t-1}$ : Total assets for firm $j$ in year $t-1, \Delta R E V_{i, i}$ Change in the revenues (sales) for firm $i$ in year $t$ less revenue in year $t-1$, $\triangle A R_{i, t}$. Change in accounts receivables for firm $i$ in year $t$ less receivable in year $t$ - 1, $P P E_{i, t}$ Gross properties, plants and equipments for firm $i$ in year $t, R O A_{i, t}$ is the net income of firm $i$ in year $t$ scaled by the lagged total assets, $\beta_{1}, \beta_{2}, \beta_{3}, \beta_{4}$ are firm specific parameters; $u_{j}$ is the mean value of the residual for firm $i$ covering the sample data; and $e_{i, t}$ is the variation from the mean residual $u_{j}$ of 
firm $i$ in year $t$.

\section{Control variables}

We use some control variables in the model as SIZEis the natural logarithm of the book value of total assets at year-end; $R O A$ is the net income divided by lagged total assets at year-end; GROWTH is the current operating revenueprior operating revenue divide beginning operating revenue; $P P E$ is the net properties, plants and equipments/ total assets at year-end; BIG4 is a dummy variable equal to 1 if the company is audited by a Big 4 audit firm, and 0 otherwise. We apply control variables that represent firm characteristics for the purpose of controlling the relationship between tax avoidance and firm leverage. These control variables are also utilised in previous studies [3] [7] [17].

\section{Results and Discussion of Results}

Table 1 represents the abstract statistics of variables employed in this research over the period 2010 to 2016.

Table 2 illustrates the correlation matrix of variables. Firm leverage $(L E V)$ is negatively correlated with corporate tax avoidance (CASHETR), and positively correlated with other corporate tax avoidance indicator (CURRENTETR, BTD). The independent variables in the model are not significantly correlated, where is distinctive constructs, and there is no multicollinearity problem $(<0.9)[18]$.

Research results show that the tax avoidance behavior has a mixed impact on the firm leverage of companies listed on the Vietnam stock market. This conclusion confirms the negative association between tax avoidance indicator (CURRENTETR, CASHETR) and firm leverage for Vietnamese listed companies, consistent with the previous studies [4] [5] [7]. This indicates that companies attempting to diminish the tax burden will boost leverage. The results of the study with a residual of earnings management show that the opposite relationship between book-tax difference and firm leverage at the 10 percent level as shown in Column (3) of Table 3. The results of this study are also consistent with previous studies. Conversely, when the temporary difference increases, the company may be avoiding tax increases or avoiding tax reductions due to temporary differences

Table 1. Descriptive statistics of variables.

\begin{tabular}{ccccccccc}
\hline Variable & LEV & CURRENTETR CASHETR & BTD & SIZE & ROA & GROWTH & PPE \\
\hline Mean & 0.5595 & 0.2189 & 0.1539 & 0.3701 & 28.0967 & 0.0595 & 1.9074 & 0.2449 \\
Std. Dev. & 0.1939 & 0.3073 & 0.1952 & 0.3165 & 1.4309 & 0.0712 & 16.8719 & 0.1945 \\
Min & 0.0404 & 0.0000 & 0.0000 & 0.0000 & 24.6898 & -0.6455 & -0.9972 & 0.0007 \\
Max & 0.9345 & 1.0000 & 0.9711 & 0.9997 & 32.8265 & 0.7837 & 328.8971 & 0.8838 \\
Obs & 875 & 875 & 875 & 875 & 875 & 875 & 875 & 875 \\
\hline
\end{tabular}

Source: the author's calculations. Notes: The table reports summary statistics of variables over the period from 2010 to 2016 for Vietnamese listed firms. LEV is firm leverage, measured as ratio of total debt over total assets. CTA is the tax avoidance indicator. SIZE is firm size, that is, natural log of assets. ROA is the ratio of net income after taxes to total assets. GROWTH is sale growth rate.PPE is the ratio of net plant, property and equipment to total assets; BIG4 is 1 if auditor is a Big 4 audit firm, and 0 otherwise. 
Table 2. Pearson correlation coefficient matrix.

\begin{tabular}{|c|c|c|c|c|c|c|c|c|c|}
\hline & LEV & CURRENTETR & CASHETR & BTD & BIG4 & SIZE & ROA & GROWTH & PPE \\
\hline LEV & 1.000 & & & & & & & & \\
\hline CURRENTETR & 0.016 & 1.000 & & & & & & & \\
\hline CASHETR & -0.072 & -0.211 & 1.000 & & & & & & \\
\hline BTD & 0.143 & 0.026 & 0.057 & 1.000 & & & & & \\
\hline BIG4 & -0.030 & -0.053 & 0.207 & 0.016 & 1.000 & & & & \\
\hline SIZE & 0.186 & -0.028 & 0.159 & 0.036 & 0.474 & 1.000 & & & \\
\hline ROA & -0.490 & -0.228 & 0.207 & -0.195 & 0.101 & 0.042 & 1.000 & & \\
\hline GROWTH & 0.031 & -0.048 & 0.096 & -0.014 & 0.010 & 0.069 & 0.043 & 1.000 & \\
\hline PPE & -0.036 & -0.022 & -0.011 & 0.022 & -0.086 & 0.121 & -0.016 & 0.007 & 1.000 \\
\hline
\end{tabular}

Source: the author's calculations. Notes: The table reports correlation matrix over the period from 2010 to 2016 for Vietnamese listed firms. LEV is firm leverage, measured as ratio of total debt over total assets. CTA is the tax avoidance indicator. SIZE is firm size, that is, natural log of assets. ROA is the ratio of net income after taxes to total assets. GROWTH is sale growth rate.PPE is the ratio of net plant, property and equipment to total assets; BIG4 is 1 if auditor is a Big 4 audit firm, and 0 otherwise.

Table 3. Dynamic GMM-Regression results.

\begin{tabular}{|c|c|c|c|c|c|c|}
\hline \multirow{2}{*}{ Variables } & \multicolumn{2}{|c|}{ Model 1} & \multicolumn{2}{|c|}{ Model 2} & \multicolumn{2}{|c|}{ Model 3} \\
\hline & Coefficient & $\mathrm{p}$-value & Coefficient & p-value & Coefficient & $\mathrm{p}$-value \\
\hline Lag of Dep. Var & 0.0268 & 0.834 & $0.2355^{\star *}$ & 0.028 & 0.1030 & 0.400 \\
\hline CURRENTETR & $0.0640^{\star *}$ & 0.041 & & & & \\
\hline CASHETR & & & $0.1329^{*}$ & 0.078 & & \\
\hline BTD & & & & & $-0.0947^{\star}$ & 0.096 \\
\hline BIG4 & 0.0583 & 0.389 & 0.0352 & 0.442 & 0.0275 & 0.587 \\
\hline SIZE & 0.0048 & 0.864 & -0.0158 & 0.395 & -0.0056 & 0.809 \\
\hline ROA & $0.4472^{*}$ & 0.052 & $0.4652^{\star *}$ & 0.043 & $0.4393^{*}$ & 0.093 \\
\hline GROW'TH & -0.0031 & 0.583 & 0.0038 & 0.401 & 0.0048 & 0.381 \\
\hline PPE & $0.8808^{\star * *}$ & 0.000 & $0.3977^{* * *}$ & 0.000 & $0.7047^{* * *}$ & 0.000 \\
\hline J-statistic & 21.4 & & 39.41 & & 28.9 & \\
\hline Prob J-statistic & 0.721 & & 0.406 & & 0.74 & \\
\hline
\end{tabular}

Source: the author's calculations. Notes: The table reports parameter estimates of the model:

$$
\begin{aligned}
L E V_{i, t}= & \mu L E V(-1)_{i, t}+\delta_{1} C T A_{i, t}+\delta_{2} S I Z E_{i, t}+\delta_{3} R O A_{i, t} \\
& +\delta_{4} G R O W T H_{i, t}+\delta_{5} P P E_{i, t}+\delta_{5} B I G 4_{i, t}+\varepsilon_{i, t}
\end{aligned}
$$

where: $L E V$ is firm leverage, measured as ratio of total debt over total assets. $C T A$ is the tax avoidance indicator. $S I Z E$ is firm size, that is, natural log of assets. $R O A$ is the ratio of net income after taxes to total assets. GROWTH is sale growth rate.PPE is the ratio of net plant, property and equipment to total assets; $B I G 4$ is 1 if auditor is a Big 4 audit firm, and 0 otherwise. ${ }^{*}{ }^{* *},{ }^{* *}$ denotes the level of significance of $10 \% ; 5 \%$ and $1 \%$ respectively.

for deferred tax assets or deferred tax liability. Temporary differences are generated by adaptability from accounting policies. According to agency theory, managers establish a profit objective, practising accounting tactics to secure it appear. Therefore, temporary differences are a consequence of these procedures 
themselves. This supports the company succeed profit targets, capital markets in the short term and can influence the long term. Temporary differences have a positive average so companies perform to pay more taxes. Therefore, there is a negative relationship between book-tax differences and corporate leverage.

The previous investigation has submitted that corporate tax avoidance is a continuous custom [2] [19], where corporate tax avoidance practices could be often used and incentivized [1] [20]. According to the trade-off theory, companies using tax shields or strategies for tax costs will benefit from tax liabilities. Therefore, it will maintain a high level of debt to achieve tax benefits. Therefore, high tax avoidance leads to high leverage [2] [4] [21].

\section{Conclusions}

The research investigates tax avoidance behavior influence on firm leverage, thereby contributing to knowledge of capital structure. Using a linear regression analysis shows that companies that accept tax avoidance behaviors maintain higher financial leverage, which is consistent with trade-off theory. The results of the study are consistent with previous studies with all three measures of tax avoidance [4] [5] [7], and contradicts the results [22]. According to Harford, Li, and Zhao [23], maturing debts are the interest of and calculated by both creditors and managers. Creditors frequently monitor debt companies but managers have little concern in creditors, consequently, leading to regular debt negotiations to serve the tax avoidance activities [22].

Our results will be empirical research that is of interest to regulators, auditors, and academic researchers. Regulatory authorities will be involved in signs to distinguish between tax evasion and tax avoidance. Auditors can assess corporate financial health through financial leverage but spend attention to the tax avoidance strategy of companies to have a comprehensive perspective. Researchers are engrossed in the topic of tax policy and the differences between economies on the relationship between tax avoidance behaviour and firm leverage. Future studies may examine the influence of tax avoidance practices on other company activities such as dividends, the relationship between tax consulting costs and tax policy decisions at the firm.

\section{Acknowledgements}

This research is funded by University of Economics and Law, Vietnam National University Ho Chi Minh City, Vietnam.

\section{Conflicts of Interest}

The authors declare no conflicts of interest regarding the publication of this paper.

\section{References}

[1] Dyreng, S.D., Hanlon, M. and Maydew, E.L. (2010) The Effects of Executives on 
Corporate Tax Avoidance. The Accounting Review, 85, 1163-1189. https://doi.org/10.2308/accr.2010.85.4.1163

[2] Dyreng, S.D., Hanlon, M. and Maydew, E.L. (2008) Long-Run Corporate Tax Avoidance. The Accounting Review, 83, 61-82.

https://doi.org/10.2308/accr.2008.83.1.61

[3] Graham, J.R. and Tucker, A.L. (2006) Tax Shelters and Corporate Debt Policy. Journal of Financial Economics, 81, 563-594. https://doi.org/10.1016/j.jfineco.2005.09.002

[4] Kubick, T.R. and Lockhart, G.B. (2017) Corporate Tax Aggressiveness and the Maturity Structure of Debt. Advances in Accounting, 36, 50-57.

https://doi.org/10.1016/j.adiac.2016.10.001

[5] Lin, S., Tong, N. and Tucker, A.L. (2014) Corporate Tax Aggression and Debt. Journal of Banking \& Finance, 40, 227-241. https://doi.org/10.1016/j.jbankfin.2013.11.035

[6] Lisowsky, P. (2010) Seeking Shelter: Empirically Modeling Tax Shelters Using Financial Statement Information. The Accounting Review, 85, 1693-1720. https://doi.org/10.2308/accr.2010.85.5.1693

[7] Platikanova, P. (2017) Debt Maturity and Tax Avoidance. European Accounting Review, 26, 97-124. https://doi.org/10.1080/09638180.2015.1106329

[8] Wilson, R.J. (2009) An Examination of Corporate Tax Shelter Participants. The Accounting Review, 84, 969-999. https://doi.org/10.2308/accr.2009.84.3.969

[9] Gaaya, S., Gaaya, S., Lakhal, N., Lakhal, N., Lakhal, F. and Lakhal, F. (2017) Does Family Ownership Reduce Corporate Tax Avoidance? The Moderating Effect of Audit Quality. Managerial Auditing Journal, 32, 731-744.

https://doi.org/10.1108/MAJ-02-2017-1530

[10] Yorke, S.M., Amidu, M. and Agyemin-Boateng, C. (2016) The Effects of Earnings Management and Corporate Tax Avoidance on Firm Value. International Journal of Management Practice, 9, 112-131. https://doi.org/10.1504/IJMP.2016.076741

[11] Arellano, M. and Bond, S. (1991) Some Tests of Specification for Panel Data: Monte Carlo Evidence and an Application to Employment Equations. The Review of Economic Studies, 58, 277-297. https://doi.org/10.2307/2297968

[12] Wooldridge, J.M. (2015) Introductory Econometrics: A Modern Approach. Nelson Education, Toronto, Canada.

[13] Cheng, C.-A., Huang, H.-H., Li, Y. and Stanfield, J. (2012) The Effect of Hedge Fund Activism on Corporate Tax Avoidance. The Accounting Review, 87, 1493-1526. https://doi.org/10.2308/accr-50195

[14] Frank, M.M., Lynch, L.J. and Rego, S.O. (2009) Tax Reporting Aggressiveness and Its Relation to Aggressive Financial Reporting. The Accounting Review, 84, 467-496. https://doi.org/10.2308/accr.2009.84.2.467

[15] McGuire, S.T., Wang, D. and Wilson, R.J. (2014) Dual Class Ownership and Tax Avoidance. The Accounting Review, 89, 1487-1516. https://doi.org/10.2308/accr-50718

[16] Kothari, S.P., Leone, A.J. and Wasley, C.E. (2005) Performance Matched Discretionary Accrual Measures. Journal of Accounting and Economics, 39, 163-197. https://doi.org/10.1016/j.jacceco.2004.11.002

[17] Frank, M.Z. and Goyal, V.K. (2009) Capital Structure Decisions: Which Factors Are Reliably Important? Financial management, 38, 1-37. https://doi.org/10.1111/j.1755-053X.2009.01026.x 
[18] Gujarati, D. and Porter, D. (2003) Multicollinearity: What Happens If the Regressors Are Correlated? In: Basic Econometrics, 4th Edition, McGraw-Hill, Boston, MA, 363.

[19] Blaylock, B., Shevlin, T. and Wilson, R.J. (2011) Tax Avoidance, Large Positive Temporary Book-Tax Differences, and Earnings Persistence. The Accounting Review, 87, 91-120. https://doi.org/10.2308/accr-10158

[20] Rego, S.O. and Wilson, R. (2012) Equity Risk Incentives and Corporate Tax Aggressiveness. Journal of Accounting Research, 50, 775-810. https://doi.org/10.1111/j.1475-679X.2012.00438.x

[21] Joulfaian, D. (2000) Corporate Income Tax Evasion and Managerial Preferences. Review of Economics and Statistics, 82, 698-701. https://doi.org/10.1162/rest.2000.82.4.698

[22] Hasan, I., Hoi, C.K.S., Wu, Q. and Zhang, H. (2014) Beauty Is in the Eye of the Beholder: The Effect of Corporate Tax Avoidance on the Cost of Bank Loans. Journal of Financial Economics, 113, 109-130. https://doi.org/10.1016/j.jfineco.2014.03.004

[23] Harford, J., Li, K. and Zhao, X.-S. (2008) Corporate Boards and the Leverage and Debt Maturity Choices. International Journal of Corporate Governance, 1, 3-27. https://doi.org/10.1504/IJCG.2008.017648 